\title{
Annual cycle of the Sertoli cell population in adult stallions
}

\author{
L. Johnson and H. B. Nguyen \\ Department of Cell Biology, The University of Texas Health Science Center at Dallas, \\ 5323 Harry Hines Boulevard, Dallas, Texas, 75235, U.S.A.
}

\begin{abstract}
Summary. Stereological methods were employed in two experiments with adult stallions: (1) to confirm seasonal variation in number of Sertoli cells and (2) to characterize the annual cycle of the Sertoli cell population. In the first experiment, testes from 28 adult (4-20 years old) horses obtained in the non-breeding season (December-January) were compared to testes from 28 adult horses in the breeding season (June-July). Sertoli cell numbers were calculated from the nuclear volume density, parenchymal volume, and volume of an individual Sertoli cell nucleus determined by reconstruction of serial sections or from average height and width measurements. The number of Sertoli cells per testis was significantly greater in the breeding season. In a second experiment involving 43-48 adult horses in each 3-month period, the Sertoli cell population was higher $(P<0.05)$ in May-July than other periods and higher $(P<0.01)$ than in November-January. These combined studies confirm seasonal differences in the Sertoli cell numbers per testis and define the annual cycle of the Sertoli cell population in adult stallions.
\end{abstract}

\section{Introduction}

The Sertoli cell has several functions in the seminiferous epithelium which are involved in support of germ cell development. Some of these include: structural support and nutrition of germ cells, spermiation of mature spermatids, movement of young germ cells, phagocytosis of degenerating germ cells and residual bodies, secretion of fluid in the lumen, secretion of proteins, formation of the blood-testis barrier, and cell-to-cell communication (Dym \& Madhwa Raj, 1977). Also, Sertoli cells produce a mitogenic polypeptide (Feig, Bellve, Erickson \& Klagsbrun, 1980). The number of Sertoli cells per testis has been shown to be elevated in the breeding season when sperm production rate was also higher (Johnson \& Thompson, 1983; Johnson, 1985a). Significant seasonal fluctuations in the absolute number of Sertoli cells of adult males have been demonstrated by Johnson \& Thompson (1983) although the animals were not sampled throughout the year. The objective of the present study was to provide further evidence of seasonal differences in the number of Sertoli cells per testis by a recently developed method (Johnson, Zane, Petty \& Neaves, 1984) and by a second experiment in which the size of the Sertoli cell population was evaluated throughout the entire year.

\section{Materials and Methods}

Specimens. Testes from 56 adult (4-20 years old) horses were obtained from a slaughterhouse in the non-breeding (December-January) or the breeding (June-July) season. Only horses from lightweight breeds, in good body condition, and having a smooth hair coat were used. Tooth replacement and wear were used to determine the age of horses. Mean ages were $10 \pm 1$ years for horses in the non-breeding season and $11 \pm 2$ years for those in the breeding season. Since no differences $(P>0.05)$ in parenchymal weights were found in horses at 4-5,6-12 or 13-20 years of age 
(Johnson \& Thompson, 1983), these three groups were pooled for data analysis and compared by the $t$ test for seasonal differences (Sokal \& Rohlf, 1969). Within $15 \mathrm{~min}$ of death, testes were removed and placed on ice. Cooled testes were freed from fascia and the epididymis and weighed. Parenchymal volume was determined by dividing the difference in averaged testicular weight and tunic weight by a specific gravity value of $1.05 \mathrm{~g} / \mathrm{ml}$ (Johnson \& Neaves, 1981). Slices (1-3 g) of parenchyma were fixed in $2 \%$ glutaraldehyde in $100 \mathrm{~mm}$-cacodylate buffer and subsequently stored at $5^{\circ} \mathrm{C}$. Pieces of fixed parenchyma were further fixed with $1 \% \mathrm{OsO}_{4}$, embedded in Epon, and sectioned (Johnson, 1985a). Sections $(0.5 \mu \mathrm{m})$ were observed by bright-field microscopy for volume density measurements. Thicker sections $(20 \mu \mathrm{m})$ were observed unstained under Nomarski optics to measure the average maximum diameter of Sertoli cell nuclei in each season.

Experiment 1: calculation of Sertoli cell number based on nuclear volume density and volume of the individual nucleus. The number of Sertoli cells per testis was calculated by dividing the product of the volume density of Sertoli cell nuclei, and parenchymal volume, and the approximated histological correction factor for section thickness and nuclear diameter assuming the most closely related spherical model (Weibel \& Paumgartner, 1978), by the volume of a single Sertoli cell nucleus for that season. This approximated histological correction factor was 0.96 for volume density of Sertoli cell nuclei. The relative section thickness (average maximum diameter divided by section thickness of $0.5 \mu \mathrm{m}$ ) was much less than the $<0.1$ cut-off point needed to correct for spherical structures (Bolender, 1978). While our correction factor lowered the estimate by $4 \%$, no correction would result in an over estimation of only a few percent (Bolender, 1978). Volume density of Sertoli cell nuclei in 28 horses from each season was based on the number of points over Sertoli cell nuclei divided by total points applied using the point-counting method and a 50-point ocular grid at $\times 1000$ magnification (Elias, Pauly \& Burns, 1978). Four sections averaging over $10 \mathrm{~mm}^{2}$ each were analysed from each of two tissue blocks per testis for a total of 448 sections analysed. Each of the 56 horses was evaluated by 5000 points/testis for a total of 140000 points per season. Precision of volume density estimates was estimated at $14 \%$ coefficient of variation. The volume of a single nucleus was determined for 5 randomly selected horses in each season by the reconstruction of serial sections (Johnson et al., 1984) through 10 randomly selected nuclei per horse. The individual nuclear volume was determined by adding individual volumes (area determined by computerized digitizing unit times the section thickness of $0.5 \mu \mathrm{m}$ measured by calibrated electron microscopy of perpendicular sections; Johnson, Petty \& Neaves, 1983) of nuclear profiles in serial sections. Precision of repeated area measurements of nuclear profiles in our laboratory was $2 \cdot 1 \%$ (Johnson et al., 1984)

Since the volume determination for individual nuclei by reconstruction of serial sections is so time consuming for each horse, the volume of a single nucleus was calculated for comparative purposes by the formula for a sphere given the average maximum diameter based on nuclear height and width. While determination of average maximum diameter from at least 25 nuclei per horse in $20 \mu \mathrm{m}$ Epon sections was more conducive to evaluation of a larger series of horses (15 randomly selected horses per season), the non-spherical shape of the Sertoli cell nucleus required multiplication by a correction factor for nuclear volume. The correction factor was calculated by dividing the average volume of individual nuclei for 5 horses in each season based on reconstruction of serial sections by the average volume of individual nuclei for the same 5 horses of that season determined by the formula for the volume of a sphere given the average maximum diameter. Since the correction factor was similar $(P>0.05)$ between seasons, a single correction factor $(0.73 \pm 0.04)$ based on all 10 horses was used for both seasons.

Experiment 2: calculation of Sertoli cell numbers throughout 1 complete year. Using the method described above (i.e. nuclear volume density and average volume of the single nucleus) to calculate the number of Sertoli cells, 43-48 adult (4-20 years) horses were studied during each 3-month period for 1 year. The average volume of individual Sertoli cell nuclei was determined from the average maximum diameter, the formula for a sphere, and the correction factor empirically derived 
in Exp. I to convert volume estimates based on the average maximum diameter and the formula for a sphere to the volume based on serial section reconstruction. Average maximum diameter was based on 25-50 nuclei measured per horse in a $20 \mu \mathrm{m}$ section from 9 randomly selected horses per season (November-January and May-July). Given no seasonal difference in the size of the average individual Sertoli cell nucleus (11.7 \pm 0.2 and $11.6 \pm 0.2 \mu \mathrm{m}$ for the two seasons, respectively), the average individual Sertoli cell nucleus was based on all 18 horses within this group. Volume density (Elias et al., 1978) was based on 5000 points scored on 8 sections from two tissue blocks for at least 86 testicular samplings and 215000 points per 3-month period.

Seasonal differences were tested for significance by the $t$ test (Sokal \& Rohlf, 1969). Differences among time periods in the second experiment were tested by the one-way analysis of variance and the Student-Newman-Keuls' test (Sokal \& Rohlf, 1969).

\section{Results}

\section{Experiment 1}

Parenchymal weight of adult (4-20 years old) horses in the non-breeding season was only $\sim 72 \%$ of that in horses of the breeding season (Table 1). A similar volume density of Sertoli cell nuclei between seasons and reduced parenchymal volume yielded significantly less nuclear volume per testis in the non-breeding season (Table 1). The average individual nuclear volumes determined by reconstruction of serial sections in testes from 5 randomly selected horses per season or by average maximum diameter based on 15 randomly selected horses per season were similar $(P>0.05)$ between seasons. Given similar volume densities and similar volume of the individual nucleus, the number of Sertoli cells/g parenchyma was similar between seasons. However, with elevated parenchymal volume in the breeding season, there was a significant $(P<0.01)$ increase in the number of Sertoli cells per testis (Table 1).

Table 1. Effect of season on the volume density of Sertoli cell nuclei, average volume of individual Sertoli cell nuclei, and number of Sertoli cells in 28 adult horses in each season

\begin{tabular}{|c|c|c|c|}
\hline & \multicolumn{2}{|c|}{ Season } & \multirow[b]{2}{*}{ Significance } \\
\hline & Non-breeding & Breeding & \\
\hline \multirow{2}{*}{\multicolumn{4}{|c|}{ Sertoli cell nuclei }} \\
\hline & & & \\
\hline Volume density $(\%)$ & $1.60 \pm 0.08$ & $1.77 \pm 0.09$ & NS \\
\hline Volume in parenchyma $(\mathrm{ml})$ & $1.59 \pm 0.12$ & $2.59 \pm 0.24$ & $P<0.01$ \\
\hline Mean maximum diameter $(\mu \mathrm{m})^{*}$ & $11 \cdot 8 \pm 0 \cdot 3$ & $12 \cdot 2 \pm 0.2$ & NS \\
\hline \multicolumn{4}{|l|}{ Averaged volume (fl) of individual nuclei based on: } \\
\hline Reconstrution of serial sections $\dagger$ & $678 \pm 71$ & $693 \pm 38$ & NS \\
\hline Mean maximum diameter (corrected)* & $651 \pm 48$ & $695 \pm 30$ & NS \\
\hline \multicolumn{4}{|l|}{ No. of Sertoli cells $/ \mathrm{g}\left(10^{6}\right)$ based on: } \\
\hline Nuclear volume (serial sections) & $22 \cdot 8 \pm 1 \cdot 2$ & $24 \cdot 0 \pm 1 \cdot 5$ & NS \\
\hline Corrected nuclear volume (mean max. diameter) & $23 \cdot 3 \pm 1 \cdot 3$ & $23 \cdot 1 \pm 1 \cdot 1$ & NS \\
\hline \multicolumn{4}{|l|}{ No. of Sertoli cells/testis $\left(10^{9}\right)$ based on: } \\
\hline Nuclear volume (serial sections) & $2 \cdot 37 \pm 0.18$ & $3.68 \pm 0.34$ & $P<0.01$ \\
\hline Corrected nuclear volume (mean max. diameter) & $2 \cdot 42 \pm 0.18$ & $3 \cdot 55 \pm 0.33$ & $P<0.01$ \\
\hline
\end{tabular}

Values are mean \pm s.e.m. for each group of animals. NS, not significant.

* Based on 15 horses per season.

†Based on 5 horses per season. 


\section{Experiment 2}

Parenchymal volumes were larger than those for the horses in Exp. 1 obtained during the same months of the previous years (Table 1). Parenchymal volumes were lower $(P<0.01)$ in NovemberJanuary $(120 \cdot 1 \pm 5.2 \mathrm{ml})$ than in May-July $(155 \cdot 1 \pm 6.4 \mathrm{ml})$. Intermediate volumes characterized February-April $(142.1 \pm 5.5 \mathrm{ml})$ and August-October $(129.9 \pm 4.8 \mathrm{ml})$. The size of the average individual Sertoli cell nucleus was similar $(P>0.05)$ between seasons when based on the average maximum diameter of nuclei found in 9 randomly selected stallions per season $(11.6 \mu \mathrm{m}$ for nonbreeding vs $11.7 \mu \mathrm{m}$ for breeding). This translated to a corrected average nuclear volume of $623 \pm 35 \mathrm{fl}$ for the non-breeding season and $608 \pm 35 \mathrm{fl}$ for the breeding season. While the number of Sertoli cells per $\mathrm{g}$ was slightly higher in May-July (Fig. 1), the absolute values were similar to those in Exp. 1 (Table 1). As the result of larger parenchymal weights, the numbers of Sertoli cells per testis were slightly above the values in Exp. 1. However, the number of Sertoli cells per testis in the May-July period was significantly greater than in any of the other three periods (Fig. 1).

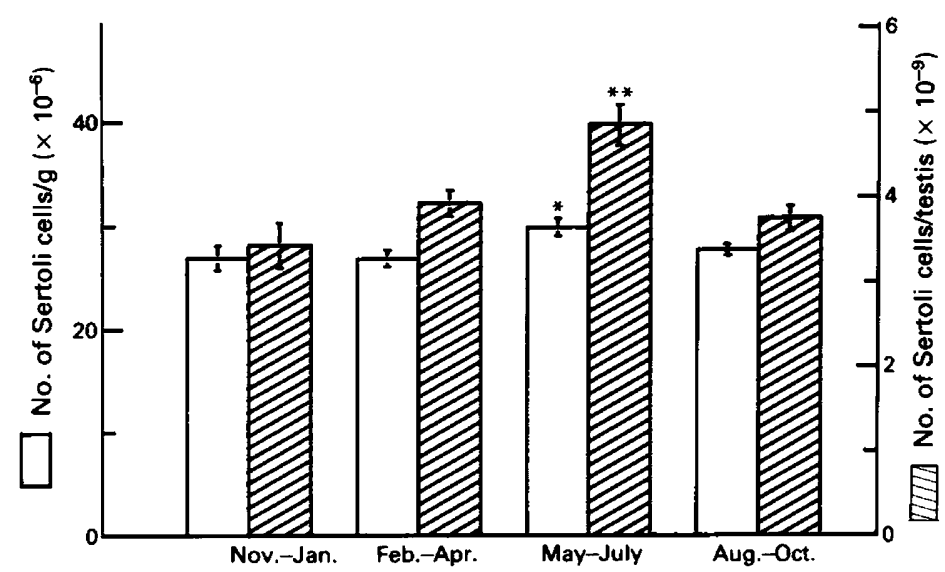

Fig. 1. Number of Sertoli cells found in 43-48 adult horses during each 3-month period throughout 1 complete year. ${ }^{*} P<0.05$ compared with other values. ${ }^{* *} P<0.05$ compared with value in August-October or February-April, and $P<0.01$ compared with value in November-January.

\section{Discussion}

The results of the present study (Table 1; Fig. 1) confirm our previous finding of seasonal variation in the Sertoli cell population of adult stallions (Johnson \& Thompson, 1983; Johnson, 1985b). In this confirmation, an unrelated approach yielded similar absolute values of numbers of Sertoli cells of adult horses in Exp. 1. Likewise, these estimates, based on histometric analysis of the volume of a single Sertoli cell nucleus (determined by the reconstruction of serial sections through the entire nucleus or based on the corrected volume from average height and width measurements of nuclei), were significantly $(P<0.01)$ higher in the breeding season (Table 1). Experiment 2, using samples taken throughout 12 months, yielded significant seasonal differences and intermediate absolute values between seasons (Fig. 1).

To our knowledge, this study represents the first estimate of volume of the individual Sertoli cell nucleus in which all three dimensions were measured in a seasonal breeder. This three-dimensional estimate was made possible by the reconstruction of serial sections through the entire nucleus (Table 1). Based on these reconstructions, there was no seasonal difference $(P>0.05)$ in the size 
(volume) of the individual Sertoli cell nucleus. The lack of seasonal variation in the average size of individual nuclei was confirmed by average maximum diameter (height and width) based on 15 horses per season in Exp. 1 (Table 1) and based on 9 randomly selected horses in the second experiment. This finding of similar nuclear size between seasons is consistent with that found for other seasonal breeders such as the red deer in which the number of Sertoli cells per testis was $36 \%$ higher (not statistically significant) in autumn than in the spring (Hochereau-de Reviers \& Lincoln, 1978).

However, variation in the cross-sectional area of Sertoli cell nuclei has been reported as part of the seasonal changes in the ram (Hochereau-de Reviers, Loir \& Pelletier, 1976) and hamster (Vendrely, Guerillot \& Da Lage, 1972), after treatment with busulfan when the number of Sertoli cells per testis were also varied (Viguier-Martinez, Hochereau-de Reviers, Barenton \& Perreau, 1984), and after flutamide treatment when the number of Sertoli cells was unchanged (Viguier-Martinez et al., 1983). In both seasons, the Sertoli cell nucleus of the horse was larger than the $512 \mathrm{fl}$ reported for the human Sertoli cell nucleus (Johnson et al., 1984). Like the nonseasonallybreeding human, similarity in size of the Sertoli cell nucleus between seasons may reflect a continued baseline functional state of the Sertoli cell throughout the year in which sperm production continues (Thompson, Pickett, Berndtson, Voss \& Nett, 1977).

While the source of additional Sertoli cells in the breeding season and their fate after the breeding season are unknown, mitotic activity and cell death cannot be ruled out as they have not been evaluated for animals in which numbers of Sertoli cells have been shown by quantitative means to change. Therefore, the failure to observe mitotic figures in Sertoli cells after 15 days of age (Clermont \& Perey, 1957) or of adult rat Sertoli cells to display mitotic figures or to incorporate $\left[{ }^{3} \mathrm{H}\right]$ thymidine in culture (Steinberger \& Steinberger, 1977) may not be applicable to seasonal changes in Sertoli cell numbers noted in the horse. Seasonal variation of Sertoli cell numbers in the stallion is a clear example of the instability of the Sertoli cell population in adults and may be fostered by mitotic activity. Sertoli cells in vitro can maintain their ability to produce androgenbinding protein while retaining their ability to undergo DNA synthesis and cell division by mitosis (Kierszenbaum \& Tres, 1981).

Interstitial growth along the length of the tubule (such as would be produced by mitotic activity) is how the Sertoli cell population is augmented in the breeding season. Our previous studies (Johnson \& Thompson, 1983) revealed no seasonal difference in the diameter of tubules, the size of the individual Sertoli cell nucleus, or the number of Sertoli cells with nucleoli per crosssection of tubules. However, the length of tubules $(1.9 \pm 0.1$ vs $2.9 \pm 0.3 \mathrm{~km})$ was greater $(P<0.01)$ in the breeding season. Positive correlations between the total number of Sertoli cells/ testis and the total length of seminiferous tubules have been reported for the rat, ram and bull (Hochereau-de Reviers \& Courot, 1978).

The absolute number of Sertoli cell nuclei per testis has been determined for different species by various methods. These include: (1) Sertoli cell counts within a given length of the seminiferous tubule (Hochereau-de Reviers \& Lincoln, 1978; Hochereau-de Reviers \& Courot, 1978); (2) Sertoli cells count per area at two section thicknesses (Bergh, 1981); (3) using the nucleolus instead of the nucleus (Wing \& Christensen, 1982; Johnson et al., 1984); (4) direct counts of Sertoli cell nuclei in homogenates of fixed testes by phase-contrast cytometry (Johnson \& Thompson, 1983; Johnson et al., 1984); (5) dividing the number of spermatids of a given type per testis by the number of spermatids with elongated nuclei which were embedded in the apex of individual Sertoli cells cut in cross-section (Johnson, 1985b); and (6) nuclear volume density and volume of individual Sertoli cell nucleus determined from reconstruction of serial sections (Johnson et al., 1984; Table 1). Confirmation of seasonal variation in the Sertoli cell numbers (Table 1) and characterization of the annual cycle of the Sertoli cell population in adult stallions (Fig. 1) indicate that efforts to reverse artificially seasonal variation in the production of spermatozoa should also consider augmentation of the size of the Sertoli cell population.

We thank the Beltex Corporation, 3801 North Grove, Fort Worth, Texas 76106, for providing 
horse tissues and Ms Karen S. Pollan and Jenifer Ratliff for technical assistance. This study was supported in part by grant HD16773 from N.I.H.

\section{References}

Bergh, A. (1981) Morphological signs of a direct effect of experimental cryptorchidism on the Sertoli cells in rats irradiated as fetuses. Biol. Reprod. 24, 145-152.

Bolender, R.P. (1978) Correlation of morphometry and stereology with biochemical analysis of cell fractions. Int. Rev. Cytol. 55, 247-289.

Clermont, Y. \& Perey, B. (1957) Quantitative study of the cell population of the seminiferous tubules in immature rats. Am. J. Anat. 100, 241-267.

Dym, M. \& Madhwa Raj, H.G. (1977) Response of adult rat Sertoli cells and Leydig cells to depletion of luteinizing hormone and testosterone. Biol. Reprod. $17,676-696$.

Elias, H., Pauly, J.E. \& Burns, E.R. (1978) Quantitative microscopy (stereology and morphometry). In Histology and Human Microanatomy, pp. 547-576. John Wiley and Sons, New York.

Feig, L.A., Bellve, A.R., Erickson, N.H. \& Klagsbrun, M. (1980) Sertoli cells contain a mitogenic polypeptide. Proc. natn. Acad. Sci. U.S.A. 77, 4774-4778.

Hochereau-de Reviers, M.T. \& Courot, M. (1978) Sertoli cells and development of seminiferous epithelium. Annls Biol. anim. Biochim. Biophys. 18, 573-583.

Hochereau-de Reviers, M.T. \& Lincoln, G.A. (1978) Seasonal variation in the histology of the testis of the red deer, Cervus elaphus. J. Reprod. Fert. 54, 209-213.

Hochereau-de Reviers, M.T., Loir, M. \& Pelletier, J. (1976) Seasonal variations in the response of the testis and LH levels to hemicastration of adult rams. J. Reprod. Fert. 46, 203-209.

Johnson, L. (1985a) Increased daily sperm production in the breeding season of stallions is explained by an elevated population of spermatogonia. Biol. Reprod. 32, 1181-1190.

Johnson, L. (1985b) Further evidence of seasonal variation in number and function of Sertoli cells in adult stallions. J. Androl. 6, 74, Abstr.

Johnson, L. \& Neaves, W.B. (1981) Age-related changes in the Leydig cell population, seminiferous tubules, and sperm production in stallions. Biol. Reprod. 24, 703-712.

Johnson, L. \& Thompson, D.L., Jr (1983) Age-related and seasonal variation in the Sertoli cell population, daily sperm production and serum concentrations of follicle-stimulating hormone, luteinizing hormone and testosterone in stallions. Biol. Reprod. 29, 777-789.
Johnson, L., Petty, C.S. \& Neaves, W.B. (1983) Further quantification of human spermatogenesis: germ cell loss during postprophase of meiosis and its relationship to daily sperm production. Biol. Reprod. 29, 207-215.

Johnson, L., Zane, R., Petty, C.S. \& Neaves, W.B. (1984) Quantification of the human Sertoli cell population: its distribution, relation to germ cell numbers, and age-related decline. Biol. Reprod. 31, 785-795.

Kierszenbaum, A.L. \& Tres, L.L. (1981) The structural and functional cycle of Sertoli cells in culture. In Bioregulators of Reproduction, pp. 207-228. Eds. G. Jagiello \& H. J. Vogel. Academic Press, New York.

Sokal, R.R. \& Rohlf, F.J. (1969) Biometry, pp. 220-508. W. H. Freeman and Co., San Francisco.

Steinberger, A. \& Steinberger, E. (1977) The Sertoli cell In The Testis vol. 4, pp. 371-399. Eds A. D. Johnson \& W. R. Gomes. Academic Press, New York.

Thompson, D.L., Jr, Pickett, B.W., Berndtson, W.E., Voss, J.L. \& Nett, T.M. (1977) Reproductive physiology of the stallion. VIII. Artificial photoperiod, collection interval and seminal characteristics, sexual behavior and concentration of $\mathrm{LH}$ and testosterone in serum. J. Anim. Sci. 44, 656-664.

Vendrely, E., Guerillot, C. \& Da Lage, C. (1972) Variations saisonnierres de cellules de Sertoli et de Leydig dans le testicule de hamster dore. Etude caryometrique. C. r. hebd. Séanc. Acad. Sci., Paris D 275, $1143-1146$.

Viguier-Martinez, M.C., Hochereau-de Reviers, M.T., Barenton, B. \& Perreau, C. (1983) Endocrinological and histological changes induced by flutamide treatment on the hyothalamo-hypophyseal testicular axis of the adult male rat and their incidence on fertility. Acta endocr., Copenh. 104, 246-252.

Viguier-Martinez, M.C., Hochereau-de Reviers, M.T., Barenton, B. \& Perreau, C. (1984) Effect of prenatal treatment with busulfan on the hypothalamo-pituitary axis, genital tract and testicular histology of prepubertal male rats. J. Reprod. Fert. 70, 67-73.

Weibel, E.R. \& Paumgartner, D. (1978) Integrated stereological and biochemical studies on hepatocytic membranes. II. Correction of section thickness effect on volume and surface density estimates. J. Cell Biol. 77, 584-597.

Wing, T.Y. \& Christensen, A.K. (1982) Morphometric studies on rat seminiferous tubules. Am. J. Anat. 165, 13-25.

Received 1 May 1985 